Yayın Geliş Tarihi: 25.01.2016

Yayına Kabul Tarihi: 20.03.2016

Online Yayın Tarihi: 02.06.2016

DOI: 10.18613/deudfd.35524

Araştırma Makalesi (Research Article)
Dokuz Eylül Üniversitesi

Denizcilik Fakültesi Dergisi

Cilt:8 Sayı:1 Yıl:2016 Sayfa:83-96

ISSN:1309-4246

E-ISSN: 2458-9942

\title{
AN EXPLORATION OF SERVICE PROBLEMS ENCOUNTERED IN SHIP AGENCY INDUSTRY
}

\section{N. Gülfem GIDENER ÖZAYDIN ${ }^{1}$}

\begin{abstract}
Ship agencies must provide flawless services in order to achieve sustainability in an increasingly competitive and globalized business environment as any other business to business service providers. This study aims to categorize the problems and the sources of problems encountered in ship agency industry in order to provide a general view of the environment whilst informing the professionals of the industry with knowledge on these problems and contribute to the ship agency literature. The problems in ship agency industry are revealed through content analysis categorization of ITIC's total 115 insurance claims regarding ship agents with respect to problem source and problem categories. The study yielded that most common service problems are regarding documentation; damage and disbursement payments and the most common problem sources are either ship agents or principles. In compliance with the findings, both parties are advised to handle their business partner selections with extreme care, utilize automated systems and software for documentation and protect themselves against inevitable service problems through liability insurance clubs.
\end{abstract}

Keywords: Ship agency, service problems, ship agency responsibilities and liabilities, maritime transport, insurance claims.

1 Asst. Prof. Dr, Dokuz Eylül University, Maritime Faculty, Izmir, ngg.ozaydin@deu.edu.tr 


\title{
GEMİ ACENTELİ̆İ SEKTÖRÜNDE YAŞANAN HİZMET PROBLEMLERININ İNCELENMESI
}

\begin{abstract}
$\ddot{O Z Z T T}$
İsletmeler arası hizmet sunan diğer her şirket gibi gemi acentelerinin de küreselleşme ve artan rekabet ortamında sürdürülebilirliklerini korumak adına problemsiz hizmet sunmaları gerekmektedir. Bu çalışma, gemi acenteliği sektöründe yaşanan problemleri ve problem kaynaklarını kategorize ederek genel durumu ortaya koymayı ve gemi acenteliği sektöründe varlığını sürdüren işletmeleri olası problemlere karşı bilgilendirmeyi ve gemi acenteliği yazınına katkı yapmayı amaçlamaktadır. Gemi acenteliği sektöründe yaşanan problemler taşımacılık sektörüne özel sigorta hizmeti sunan ITIC adlı kuruluşun veri tabanında yayınlanmış olan 115 adet sigorta talebi incelenerek yaşanan problemlerin kaynă̆ ve kategorisi bağlamında içerik analizi ile sinıflandırılarak ortaya konulmuştur. Yapılan çalışma sonucunda en sık yaşanan hatalar dokümantasyon, hasar ve masraf ödemeleri konularında olup yaşanan problemlerin kaynă̆ının da genellikle gemi acenteleri veya temsil olunanlar olduğu açı̆̆a çıkarılmıştır. Bu bağlamda, her iki tarafa da iş yapacakları kişileri seçerken daha dikkatli davranmalarını, otomatize sistemler ve dokümantasyon yazılımları kullanmalarını ve önlenemeyecek hatalardan da korunmak adına sorumluluk sigorta kulüplerine üye olarak kendilerini garanti altına almaları önerilmektedir.
\end{abstract}

Anahtar Kelimeler: Gemi acenteliği, hizmet problemleri, gemi acentesi sorumluluklarl, deniz taşımacılığı, sigorta talepleri.

\section{INTRODUCTION}

Failures in maritime sector are far more significant when compared to other sectors due to the delicate nature of maritime services. The delicacy of the aforementioned services is mostly generated from two dimensions: the time sensitivity and the multiplied impact due to the business-to-business (b2b) nature of maritime services.

The first is related with the globalization, rapidness of the international businesses, the role of maritime services in distribution and the required flexibility levels for sustainability. On the other hand, the second is due to the $\mathrm{b} 2 \mathrm{~b}$ environment meaning that the disturbances of maritime services do not only impact the service customer but also their customer as well. Hence, the impact is on the whole supply chain and creates a multiplied effect, especially monetarily. 
In addition, the service recovery is also a challenge in maritime industry since; the customers employ a more professional attitude towards the service they receive and also because of the aforementioned financial implications of service failures. The bigger the financial implication, the harder it is for the maritime service provider to amend the failure and succeed in service recovery.

This study aims is to provide information for the professionals of the ship agency industry against the possible problems in the industry. This goal is achieved through content analysis and problem source categorizations. Also, considering the limited nature of ship agency literature this study also aims to contribute to the literature by presenting examples of claims.

This paper consists of a brief literature on the intermediaries in maritime industry, what they are, what functions and roles they undertake and continue with a closer look at ship agents. The definition, responsibility and liabilities of ship agents are examined within the related literature. Afterwards, the methodology is explained and the results of study and claim examples with respect to problem source categorizations are presented and the paper is concluded.

\section{INTERMEDIARIES IN MARITIME INDUSTRY}

Ship agents and forwarders play an important role in maritime transportation with regard to effective service management; these intermediaries enable providing effective, economic, safe, secure and quality logistics and maritime services (Tuna, 1998). The importance of intermediaries in maritime industry has risen with respect to the increasing pressure of competition and the preference of focusing on core businesses whilst outsourcing the rest. Another reason why intermediaries are widely utilized in maritime industry is the factor of familiarity. Most of the time, principals and ship owners are usually not acquainted with one another and prefer to work with familiar, local ship agents and forwarders (Cerit and Önce, 1998; 2004).

\subsection{Functions and the Role of Intermediaries in Maritime Industry}

Ship agents and forwarders are mostly members of the liner (container) transport distribution channels. The distribution channel may employ only ship agents or both ship agents and forwarders for 
connecting with customers. (Deveci and Çetin, 2013: 475). The first is called one-layer liner maritime transport and the latter is called two-layer liner maritime transport. Within such a distribution channel, ship agencies represent ship owners and principles and provide services to them while forwarders represent shippers and provide services to them (Deveci and Cerit, 2007). It was also underlined that due to the complexity of logistics and transportation services, utilization of intermediaries such as ship agents and forwarders are a necessity (Deveci and Cerit, 2007).

The intermediaries undertake four responsibilities for shippers: transportation services, logistics services (consolidation, transfer, packaging, storage, labelling etc.), information systems services (tracking and tracing, freight and customs taxes, money transfer, documentation), professional consultancy and support services (Long, 2012; Tuna and Deveci, 2009). On the other hand, intermediaries undertake three responsibilities for carriers: sales and marketing, transportation equipment supply, enable service diversity and quantity. (Gray and Kim, 2001: 107).

\subsection{Definition, Responsibilities and Liabilities of Ship Agents}

Ship agents basically form a bridge between ship owners and principles. For an agency relationship to be formed: there has to be mutual trust among ship owners and ship agency, required documentation and information must be exchanged, parties should get to know one another and desire to form a relationship, a legal relationship must be formed through agency agreement, procuration agreements and authorization, the agency must be reputable, able to carry out agency duties, recognized by local authorities and finally there should not be a conflict of interest between parties (Deveci, 2002).

Ship agents provide services related with marketing and sales, booking, container delivery, road transport, port services, preparing required documentation such as the manifest, $\mathrm{B} / \mathrm{L}$ and bills, container tracking and tracing and customer relations in liner transport. In addition, ship agents carry out commercial, information systems related, operational, financial and legal functions (Deveci, 2002).

These commercial responsibilities and liabilities of ship agents refer to marketing sales functions such as: pricing, promotion, booking, market and competition analysis, customer relations management, billing and customer complaint handling thus, generally handling commercial interests of the liner carrier, generate as much work as possible, nurture 
long-term relationships with customers, retain existing customers and attract new ones. These responsibilities are deemed highly significant due to the fact that they generate the majority of the ship agents' income (ICS, 2012; Deveci and Çetin, 2013: 483; Cerit and Önce, 1998).

The responsibilities and liabilities concerning information systems and documentation are: providing information on ship's physical conditions, the port of origin, cargo and delivery port to the required government bodies before the ship arrives, carrying out health, safety and customs controls, applying to ports for loading and unloading activities, handling port and conservancy dues, requesting towage and pilotage services during ship's arrival, tracking the ship's operations, coordinating between parties, keeping SOF (Statement of Facts) and getting it signed, arranging for bunker, repair, crew, passengers, spare parts, technical support, medical support, effectively managing activities of terminal operators, stevedores, tally clerks and other parties and informing the ship owner regularly whilst the ship is at port. The responsibilities and liabilities regarding information services continue with getting the required permissions from government bodies after the operations are completed, carrying out port, health, safety and customs controls before the ship's departure, advising the ETA and ship's requirements on arrival to the Agent et next port after the ship's departure and providing related statistical data, reporting on bookings and freights and providing ship's information to Turkish Straits are the other responsibilities of ship agents regarding information systems and documentation (Deveci and Tuna, 1998; DTO and VDA, 2007; ICS, 2012).

The operational responsibilities and liabilities of ship agents are: ship and crew assistance, communication with third parties, governmental operations, inland transport arrangements, documentation and other operational functions (Deveci, 2002). The financial responsibilities and liabilities of ship agents are: freight collection, port expenses and expenditure calculation and payment, giving advances to crew, currency exchange etc. (Eröztürk, 1985; Schiels, 1995; DTO and VDA, 2007). Finally, the legal responsibilities and liabilities of ship agents are: handling the legal aspects of $\mathrm{B} / \mathrm{L}$ and cargo claims, noting protest, general average practices, taking precautions, managing security operations, overall acting on behalf of the ship owner (ICS, 2012).

The general roles of ship agents are: booking the vessel in and out of the port, and arranging the pilot and tug boat services, providing information on the crew and passengers to local immigration authorities and organizing crew changes, ensuring the ship's documentation 
complies with international regulations, preparing quarantine pre- arrival report (QPAR), advising customs of the ship's arrival and cargo, logistics involved with provisions and bunker, providing the stevedores and terminal operators with the manifest and liaising with these parties regarding safe handling of containers, break- bulk and bulk liquids and ensuring the ship's master is aware of shore requirements, paying the crew, handling ship services such as repairs and maintenance (www.fonasba.com).

Furthermore, the ship agents' liabilities are advised to be separated into two groups by the ITIC claims manager Julia Mavropoulos: the ones they face due to their own fault and due to fault of the principal. In addition, it is also expressed that more than $20 \%$ of all the claims they receive are due to principal's fault. These liabilities are related with tasks ship agents undertake for their principles such as: arranging berthing, loading, discharging, booking cargoes, quoting rates, liaising with other parties, arranging supply of goods and services, issuing documents, releasing import cargo and informing principal (Mavropoulos, 1999).

\section{METHODOLOGY}

The purpose of this study is to determine the types of failures experiences by ship agents both by their own fault or by the fault of others, explore the frequency of the failure types and provide useful information for practitioners of the field through content analysis.

All the data utilized in this study is obtained from International Transport Insurance Club's claims examples. ITIC is the mutual insurer for the transport industry with no external shareholders or underwriter to take profit from the business; it offers professional indemnity policy to a wide range of companies in the transport industry (www.itic-insure.com). The knowledge zone of ITIC's website includes 743 documents related with ship agents, shipbroking, ship management, marine surveyor, naval architecture, offshore professionals, rail, aviation, general and claims and incidents, among these documents 337 are listed under claims and incidents section. There were 115 claims examples listed in the ship agency section and all of these 115 claims examples related with ship agents were analyzed with respect to the source and the type of the failure. The pre-determined failure types are: bankruptcy, booking, cargo loss, container tracking, crew assistance, customs, damage, delay, documentation, fraud, liaising with other parties, port services, quoting rates, releasing cargo, unpaid disbursements and wrong delivery. 
The data analysis was conducted through content analysis. The aim of content analysis is to reach concepts and relationships which enable the explanation of collected data. The main purpose of this method is to discover similar data and gather them around certain concepts and themes for exploratory purposes (Yıldırım and Şimşek, 2008). The content analysis is an inductive method useful for exploring phenomenon and reaching prepositions. This method has four steps: data coding, theme forming, arranging codes and themes, interpreting and defining findings (Saruhan and Yıldız, 2013; Yıldırım and Şimşek, 2008).

Data coding can be carried out variously: coding according to predetermined concepts, coding according to concepts derived from data, coding within a general scope. Coding according to the pre-determined concepts is relatively easier since extra time for code determination is not necessary. Coding according to concepts derived from data is especially useful in subjects with no theoretical base. In this type of research, the researcher reads the data carefully and determines significant dimensions within the scope of the research. The codes are produced directly from the data through inductive analysis. The coding within a general scope is a combination of the first two coding methods; a general theoretical structure is formed apriori and coding is carried out with respect to that structure. The content analysis is guided with the pre-determined code list whilst newly discovered data produced by inductive analysis of the data is either added to the code list or switched with some pre-determined ones if deemed more appropriate. In this type of coding process, general categories or themes are pre-determined and more detailed codes within these themes are derived from data analysis (Yıldırım and Şimşek, 2008).

This study has utilized coding within a general scope; predetermined themes with regard to the ship agent's responsibilities and liabilities were selected as problem types and the actors in the industry are selected as failure source codes. The incidents were read and analyzed with regard to the pre-determined codes but also, new codes were derived from the data for providing a better understanding of the phenomenon.

Reliability is a key component in qualitative methods due to the possible influence of subjectivity. The reliability of this study is achieved through inter-judge reliability; two academicians conducted coding processes separately and the results were compared afterwards. This study has reached $85 \%$ percentage of agreement. 


\section{RESULTS OF THE STUDY}

The reported claims were analyzed and 17 problem classifications were identified with regard to ship agents' responsibilities and liabilities (see Table 1). These classifications are: arranging berth and terminal, arranging customs clearance, booking, bankruptcy, communication, container tracking and tracing, crew assistance, arranging departure of the ship, documentation, due diligence on cargo, fraud, invoicing, liaising with third parties, quoting rates, releasing cargo, disbursement payment and delivery.

Moreover, problem sources are classified as consignee, sub-agent, principals (ship owners, carriers, commercial managers, shipping lines, ship operators and time charter operators), ship agents (port agents and liner agents), shipper, third parties (ports, hauliers, stevedores), and incidents where the problem source is unknown.

Table 1: Problem Classification Frequency Table

\begin{tabular}{|l|c|c|c|}
\hline Problem Classification & $\begin{array}{c}\text { Count } \\
(\mathrm{N})\end{array}$ & $\begin{array}{c}\text { Percentage } \\
(\%)\end{array}$ & $\begin{array}{c}\text { Cumulative } \\
\text { Percentage (\%) }\end{array}$ \\
\hline Documentation & 18 & 15,7 & 15,7 \\
\hline Disbursement Payment & 18 & 15,7 & 31,4 \\
\hline Due Diligence on Cargo & 17 & 14,8 & 46,2 \\
\hline Booking & 10 & 8,7 & 54,9 \\
\hline Quoting Rates & 9 & 7,8 & 62,7 \\
\hline Releasing Cargo & 9 & 7,8 & 70,5 \\
\hline Bankruptcy & 5 & 4,3 & 74,8 \\
\hline Fraud & 5 & 4,3 & 79,1 \\
\hline Liaising with Third Parties & 5 & 4,3 & 83,4 \\
\hline Arranging Customs Clearance & 4 & 3,5 & 86,9 \\
\hline Delivery & 4 & 3,5 & 90,4 \\
\hline Arranging Berth And Terminal & 3 & 2,6 & 93 \\
\hline Container Tracking And Tracing & 3 & 2,6 & 95,6 \\
\hline Communication & 2 & 1,7 & 97,3 \\
\hline Crew Assistance & 1 & 0,9 & 98,2 \\
\hline Arranging Departure of The Ship & 1 & 0,9 & 99,1 \\
\hline Invoicing & 1 & 0,9 & 100 \\
\hline TOTAL & 115 & 100 & \\
\hline
\end{tabular}

The most frequently observed problems within the ITIC's claim examples are related to documentation, disbursement payment and due diligence on cargo. On the other hand, the most common problem source 
is the ship agents (73), and the next most frequently observed problem source is the principals (31) (See Table 2).

Table 2: Problem Source Classification Table

\begin{tabular}{|l|c|c|c|}
\hline Problem Source Classification & $\begin{array}{c}\text { Count } \\
(\mathrm{N})\end{array}$ & $\begin{array}{c}\text { Percentage } \\
(\%)\end{array}$ & $\begin{array}{c}\text { Cumulative } \\
\text { Percentage (\%) }\end{array}$ \\
\hline Ship Agent & 73 & 63,5 & 63,5 \\
\hline Principal & 31 & 27,0 & 90,5 \\
\hline N/A* & 5 & 4,3 & 94,8 \\
\hline Third Parties & 3 & 2,6 & 97,4 \\
\hline Consignee & 1 & 0,9 & 98,3 \\
\hline Sub- Agent & 1 & 0,9 & 99,2 \\
\hline Shipper & 1 & 0,9 & 100 \\
\hline $\begin{array}{l}\text { TOTAL } \\
* \text { Problem source not available. }\end{array}$ & 115 & & \\
\hline
\end{tabular}

\section{Problem Source Category Examples:}

The following examples are given in order to provide more information on the problem sources in ship agency industry. These problem sources are categorized as consignee, sub-agent, principal, ship agent, shipper, third parties and not available as seen in Table 2.

Consignee: "The ship agent took delivery of a container of nickel silver scrap valued at US\$ $34,222.80$ on arrival at Calcutta from Kaohsiung. Shortly after arrival the consignee, a sole trader, called at the agent's office claiming to be the legal owner of the cargo and seeking a delivery order. He said the original $\mathrm{B} / \mathrm{L}$ had been misplaced and offered to provide an indemnity in the usual form in which his bank would join. The agent agreed to the request and provided and indemnity from in the shipping line's recommended wording for completion.

The consignee returned later with the indemnity which appeared to be in order, and was given a delivery note to enable him to take delivery of the goods. Shortly afterwards, the shipper informed the line that he had not received payment for the goods and that the original Bill of Lading remained in the possession of the Bank. Thereupon the agent wrote to the consignee demanding immediate production of the original Bill of Lading and also wrote to the Bank requesting them to make payment to the shipper. The consignee replied sending a copy of a letter he had sent to the shipper rejecting the cargo and alleging serious shortage and excessive quantities of plastic and dust in the scrap". 
Sub-Agent: "A company was appointed as a sub-agent by the general agent of a shipping line and instructed to complete the documentation on its behalf for most of the chartered ships represented by them. In that capacity, the sub-agent received bills of lading for a shipment of logs in several lots from a New Zealand port and simultaneously received from the general agent bill of lading amendments.

The bills, which were completed by the sub-agent in accordance with instructions received from the general agent, were to be claused "Freight payable as per c/p dated ...". Unfortunately, before releasing the bills, the sub-agent also erroneously stamped each bill "Freight prepaid". The freight was due to be paid in stages and the shipper met the first payment but failed to pay the second instalment. The shipper subsequently ceased to trade."

Principal: "Several offices of a large ship agency had provided services to a ship owner's owned ships and to one that had been chartered-in. Outstanding fees and disbursements totaled nearly US $\$ 200,000$. Several months later, the ship owner had still not paid the disbursement accounts and the Club was asked to recover the debts. The entire fleet was placed under surveillance and lawyers throughout the world were instructed to arrest any ship associated with the owner in question."

Ship Agent: "A new regulation was issued by local maritime authorities in South America, stipulating the type and number of tugs to be used depending on the size of a vessel. A ship agent provided a pro forma invoice to a ship-owner, but incorrectly accounted for the number of tugs to be used."

Shipper: "The carriers of a cargo of $21 \times 40$ ' containers of acetate tow, which was discharged at a U.S. port from Brazil, instructed their local agents to arrange for the goods to be reloaded into containers belonging to another shipping line and transported to Houston to connect with the other line's service to Hong Kong. The local agents also received an instruction from the owners of the goods to arrange for new descriptive labels to be affixed to the pallets of acetate tow before the goods were reloaded. The new labels were provided by the owners of the goods and were passed by the agent to the company employed by him to reload the goods into the line's containers. The agent then arranges for the containers to be trucked to Houston where they were loaded on to a ship for carriage to Hong Kong." 
Third Parties: "A liner agent Member in the UK received two separate requests from the same glass manufacturer for open-top containers to be positioned at their premises for loading with high-tech glass and thereafter carriage to the Far East on the line's regular service. One container was destined for Bangkok and the other to Jakarta. The line's regular sub-contracted hauliers were given instructions to take a specifically numbered container to pick up the Bangkok cargo and a second specifically numbered container to pick up the Jakarta cargo. The inevitable happened and the Bangkok cargo was loaded into the Jakarta container, and vice versa. Once the job records reached the road haulier's offices the mistake was discovered and the haulier verbally informed the agent of the mistake. Unfortunately, the agent issued Bs/L bearing the wrong container numbers and the containers were cross-delivered."

\section{CONCLUSION}

As it is clearly demonstrated above, the most frequent problems that were subject to claims ITIC has received were regarding ship agents and principles. In compliance with the findings of Mavropoulos (1999), the percentage of claims derived by the fault of principals is $\% 27$ however; \%63, 5 is by the fault of ship agents. The general problem type by the fault of principles is related to liabilities of ship agents due to either unpaid disbursements by principles or the bankruptcy of principles whereas; problems by the fault of the ship agency are related to employee omissions, negligence and system errors. Therefore ship agents are advised to reconsider their own operations in order to avoid such incidents especially; documentation and due diligence on cargo.

Likewise, the most common problem was risen due to an error in documentation process, disbursement payments and the lack of due diligence on cargo. Therefore, it can be concluded that both principals and ship agents must pay extra attention to whom which they engage in business with; most of the times the principal's negligence concerning disbursement payments concluded in the ship agent held accountable whereas the ship agent's lack of due diligence on the cargo concluded in damage on the cargo which leads to both financial implications and time loss. Due to the time sensitivity of maritime operations time loss can create major consequences for all parties participating in the overall process; the whole supply chain is influenced by the error. Therefore, within the context inability to attain timeliness must be avoided.

The errors concerning documentation are generally related with human error which can be eliminated or reduced through utilization of 
technological advancements such as software which enables seamless information share among the supply chain and eliminates human error possibility by reducing the number of individuals contributing to the process. However, one of the incidents mentioned utilization of such a software lead to documentation errors since the workload got so overwhelming for the two employees responsible for data entry. Thus, the number of individuals put in charge of data entry must be in compliance with the relative work load for eliminating such incidents. The reduction in the number of individuals contributing to the process implies the reduced number of various employees of all the separate companies within the supply chain re-entering the data due to a lack of software and an automated system. The documentation information could be shared with the principal beforehand for validation purposes in order to prevent such incidents.

Although due diligence on cargo is one of the responsibilities and liabilities of the ship agent to the principal, unfortunately this is not always the case; sometimes due to various reasons the cargo gets damaged. The most frequent due diligence on cargo problems were related with the temperature settings of reefer containers.

Another error that is so common in ITIC claims is related to disbursement payments, in some of the cases the principle was a renounced company with good credibility therefore, there is no knowing that they might cause such problems but even those companies have caused problems to their agents regarding unpaid disbursements. However, if the agent is not a member of the Club the likeliness of obtaining the funds would be most challenging and maybe even impossible. Therefore, it is highly recommended for both parties to ensure themselves through insurance club membership in order to spare their businesses such pleasantries in the future.

Finally, considering that most of the problems are human based: professional personnel trainings could be undertaken. Also in order to prevent system failures quality management systems, procedures and control mechanisms should be formed.

Future studies could research all the problem categories by basing the entire research on them and deliver more detailed findings related to each category. Likewise, in-depth interviews with ship agents can be conducted to explore the root causes of the aforementioned problems. Also, a study specifically focusing on eliminating and preventing such 
problems and searching for a way to recovery could be conducted to better serve the practitioners.

\section{REFERENCES}

Cerit, A.G. and Önce, G. (1998). Denizcilik Acentelerinin Satı̧̧ Yönetiminde İlişki Pazarlama. A.G. Cerit, H. Kişi and F. Yercan (Eds.), Çă̆daş Denizcilik Stratejileri, İşletme Yönetimi Yaklaşımı (s.85-102). Izmir: Dokuz Eylül Yayınları.

Cerit, A.G. and Önce, G. (2004). How do maritime agencies perceive shippers? - A relationship marketing approach. In: Proceedings of IAME 2004 Conference, (p.1015-1026). Izmir, Turkey.

Deveci, D.A. (2002). Konteyner taşımacılı̆̆g gemi acenteliği hizmet hatalarını ölçmeye yönelik bir araştırma: İzmir limanındaki gemi acentelerine yönelik uygulama, Doktora Tezi, İstanbul Üniversitesi Deniz Bilimleri ve İşletmeciliği Ensititüsü, İstanbul.

Deveci D. A. and Cerit, A.G. (2007). Bütünleşik (çoklu) taşımacılık hizmetleri sektörünün dağıtım kanalında rekabet ve çatışma. 12. Ulusal Pazarlama Kongresi Bildiriler Kitabı. Sakarya Üniversitesi, Sakarya.

Deveci D.A. and Çetin, İ.B. (2013). Gemi Acenteleri ve Forvarder İşletmeleri. A. G. Cerit, D.A. Deveci and S. Esmer (Eds.), Denizcilik İşletmeleri Yönetimi (s. 473- 502). İstanbul: Beta Yayınları.

DTO (Deniz Ticaret Odas1) and VDA (Vapur Donatanları ve Acenteleri Derneği) (2007). Gemi Acenteliği Eğitimi, İstanbul: DTO Yayın No: 73.

Eröztürk, E. (1985). Deniz Taşımacılı̆̆ında Acenteliğe Başlarken. İstanbul: Türkiye Denizcilik İşletmeleri Basımevi.

Gray R. and Kim, G. (2001). Logistics and International Shipping. Korea: Institute of International Maritime Affairs.

ICS- Institute of Chartered Ship Brokers (2012). Shipping Business. Scotland: Witherby Publishing Group Ltd.

Long, D. C. (2003). International Logistics: Global Supply Chain Management. Dordrecht, Netherlands: Kluwer Academic Publishers. 
Mavropoulos, J. (1999). Ship Agents- Liability Problems and Exposure to Claims. UK: BIMCO

Saruhan, Ş. C., and Yıldız, M. L. (2013). Çă̆daş Yönetim Bilimi. İstanbul: Beta Basım Yayım Dağıtım.

Schiels, K.T. (1995). Ship Agency: A Guide to Tramp Ship Agency. Essex: Fairplay Publications.

Tuna, O. (1998). Lojistik Bir Hizmet Olarak Konteyner Taşımacılığı ve Dağıtım Kanalı Yapısının Analizi, A.G. Cerit, H. Kişi and F. Yercan (Eds.), Çă̆daş Denizcilik Stratejileri, Işsletme Yönetimi Yaklaşımı (s. 115124). Izmir: Dokuz Eylül Yayınları

Tuna O. and Deveci, D.A. (2009). Entering International Markets: Logistics and Distribution Channel Approach. İzmir: İlkem Ofset.

Yıldırım, A. and Şimşek, H. (2008). Nitel Araştırma Yöntemleri. Ankara: Seçkin Yayınevi.

\section{Internet References:}

http://www.fonasba.com, Access Date: 15.01.2016

http://www.itic-insure.com, Access Date: 15.01.2016 